\title{
MODIFICATION OF CERAMICS AN D CERAMIC GLAZERS WITH CARBON NANOADDITIVES, AND PROPERTIES OF THE MODIFIED MATERIALS
}

\author{
Oleg Zelenskii ${ }^{1}$, Volodymyr Shmalko ${ }^{1}$, Evgen Panov², Tetiana Shylovych ${ }^{2}{ }^{*}$, \\ Yaroslav Shylovych², Maryan Rudkevich ${ }^{3}$
}

https://doi.org/10.23939/chcht13.02.247

\begin{abstract}
The work describes a method of modifying the ceramic materials by introducing carbon-based nanoscopic additives into the slip composite and glaze composite in the form of water-based suspension for the production of sanitary and technical ceramics of increased quality. Physical and mechanical properties of experimental samples are researched. The results of experimental research are obtained in the form of experimentally determined properties of composite materials which were nanomodified by carbon nanostructures.
\end{abstract}

Key words: nanostructure, ceramics, glazer, sanitary ware, porosity, contact angle of wetting.

\section{Introduction}

Sanitary and building ceramic products are manufactured by casting in molds made of gypsum or other similar porous materials, which is then followed by drying and kiln burning. The first burning is intended to give the shard certain mechanical strength and porosity for water absorption, after which the sanitary ware is covered with a layer of glaze, which gives the product chemical resistance and mechanical sustainability. The ceramic glaze is completely sintered during the second burning in such a way that it obtains the required aesthetic qualities of the surface and at the same time turns the coating into a barrier that is impassible for fluids. After the burning, ceramic glaze usually has zero porosity and is resistant to abrasion and exposure to acids, alkalis and dyes. For sanitary ceramics, the strength and quality of the glaze are indicatively important qualities. The quality of ceramics,

\footnotetext{
${ }^{1}$ Ukrainian State Coal-Chemistry Institute,

7, Vesnina St, 61023 Kharkov, Ukraine

${ }^{2}$ National Technical University of Ukraine "The Igor Sikorsky Kyiv Polytechnic Institute",

37, Peremogy Ave., 03056 Kyiv, Ukraine

${ }^{3}$ Orgtechdiagnostics Ltd, 7a, Naukova St, 79013 Lviv, Ukraine

*tshilovich1967@ukr.net

(C) Zelenskii O., Shmalko V., Panov E., Shylovych T., Shylovych Ya., Rudkevich M., 2019
}

glazes and other composite building materials increases with the addition of various additives and modifiers.

In the recent studies, nanoparticles of various origins and morphologies have been used as modifiers. The addition of nanoparticles dispersed in material matrices usually results in a significant improvement in the properties of the composite material, depending on its nature, namely, mechanical, electrical, magnetic, optical, catalytic, and other characteristics [1, 2]. The most promising areas of nanotechnology use in construction branch is nanoparticle reinforcement and development of self-cleaning surfaces [3].

The studies of materials with addition of carbon nanotubes (CNTs) are of particular interest. Inclusion of CNTs in the ceramic matrix creates composites with high strength and improved mechanical properties compared to single-phase ceramic material [2]. For cementitious binder materials, the dispersion of multilayer carbon nanotubes Graphistrength TM manufactured by Arkema, with the outer diameter of $10-15 \mathrm{~nm}$, the length of $1-15 \mu \mathrm{m}$ and the average density of $50-150 \mathrm{~kg} / \mathrm{m}^{3}$ was used [4]. As a surfactant in the distribution of carbon nanotubes in the initial product "master batch CW2-45" carboxymethylcellulose was used. As a result, dispersions of carbon nanosystems with an effective diameter of $168.3 \mathrm{~nm}$ and with the smallest diameter of $73.3 \mathrm{~nm}$ were obtained [4]. The mechanical strength of the modified concrete increases, as the established quantity of the nanotubes added made up to $0.0065 \%$ from the whole mass of concrete used. It is estimated [5] that if $0.005 \%$ of the carbon nanomaterial of the foamed concrete entire mass is used, its strength increases by 1.7 times and thermal conductivity decreases by $20 \%$. Vaganov et al. [6] show that addition of $0.005 \%$ of carbon nanomaterial allows to increase the material tensile strength by $70 \%$, and to form an isolated system of closed pores inside the structure of the material. Clay, if modified with $0.005 \%$ of multi-layered carbon nanotubes from whole mass of the material, increases in strength of the raw material from 4.6 to $8.6 \mathrm{~kg} / \mathrm{cm}^{2}$, and the strength of a ceramic shard increases by 2.4 times. 
Yakovlev et al. [8] conclude that addition of carbon nanotubes leads to the structuring of the concrete matrix creating a dense defectless hydrosilicate calcium coating covering the surface of the hard phase, including particles of cement and filler, which provides increased surface adhesion. Furthermore, self-repair of cracks is observable in such structures due to stimulated growth of new formations inside the defects of concrete matrix. The increase in contact interactions of structured boundary layers leads to the formation of spatial framework cells in the structure of the modified cement matrix, which causes a sharp hardening of its structure due to the formation of spatial packing [8]. The introduction of carbon nanotubes into cement concretes of dense structure makes it possible to improve the structure of the cement matrix by compacting calcium hydrosilicates. This increases the strength and crack resistance of products from modified concrete, which determines its durability. In aerated concrete, the introduction of carbon nanotubes results in the structuring of the silicate matrix with a change in the morphology of the neoplasms and the formation of the calcium hydrosilicates of the lamellar structure that cover the pore surface [9].

When introduced into polymeric composite, nanoparticles act as a structuring additive. Thus, certain structuring of polymeric chains occurs, reducing the number of possible types of conformations. Studies have shown that the introduction of a small amount (up to $0.3 \%$ ) of ultradisperse carbon and multilayered carbon nanotubes into polypropylene leads to an increase in the modulus of elasticity from 1600 to $2140 \mathrm{MPa}$ (increase by $33.75 \%$ ) and increase in tensile strength from 36 to $40.5 \mathrm{MPa}$ (by $12.5 \%$ ). At the same time, the effect of the carbon fillers on the elastic-strength properties of binary mixtures of polypropylene-triple ethylene-propylene rubber is not so unambiguous [10]. There are several hypotheses regarding the effect of nanomaterials on the properties of composite materials they are introduced to. According to one of the hypothesis, primary nanomaterials possessing excess surface energy influence the structure formation of the matrix material, promoting the formation of a dense and strong substance; another hypothesis suggests that nanomaterials are the centers of crystallization inside the molecular structure of the composite. Moreover, there is a possibility that nanomaterials assemble on the crystals surface, preventing their coarsening, recrystallization and reduce the density of bulk defects [11].

The use of nano-sized additives for the production of ceramics makes it possible to significantly intensify the sintering processes, which helps the material to harden. The purpose of current work is to produce nanomodified ceramic materials and experimental studies of the strength and other characteristics of the resulting composite materials. For these purposes carbon nanoparticles were used as modifiers. The enhancement of sanitary ceramics strength provides the reduction of raw materials consumption, as well as energy consumption during production and transportation. The main advantage of the type of nanoparticles used in this work is the possibility of their cheap production from coke-chemical waste, which will allow to obtaine carbon nanomaterials at a cost well below such popular and well-known materials as carbon nanotubes, the cost of certain types of which reaches up to $\$ 380$ per 1 gram.

\section{Experimental}

To study the influence of nanoadditives, being introduced into ceramic composite, the samples of ceramics and standard glazes (without modifiers) and the samples that were modified with carbon nanoparticles have been produced. For the production of ceramics samples, a batch of standard slip was used, prepared by the method of wet mass grinding, including clayey elements, thinners and float glazers, with the moisture content of $16-20 \%$, used in production conditions. The composition of the slip included a mixture of initial components, previously thermoactivated by forging at the temperature of 1173-1473 K with the following ratio of components (wt \%): clay component 25-65; thinners $15-$ 50 ; floats $0-40$.

Carbon nanostructures (CNS) obtained from pitch coke (characteristics are given in Table 1) were used according to the procedure described in [12]. Pitch coke was dispersed to grain size $<0.2 \mathrm{~mm}$ and then exposed to ultrasonic treatment in distilled water for $30 \mathrm{~min}$ at the frequency of $22 \mathrm{kHz}$ with ultrasonic generator power of $100 \mathrm{~W}$. The obtained suspension was centrifuged (rotor speed $8000 \mathrm{rpm}$ ) for $15 \mathrm{~min}$ to remove amorphous carbon. The centrifugate was filtered to remove microparticles of amorphous carbon and carbon nanostructures aqueous suspension was obtained.

The morphology and dimensions of the added nanoparticles were examined on a transmission electron microscope PEM 125K equipped with a digital imaging system. A sample of the suspension was applied to a graphite microscope mesh (6 $\mathrm{mm}$ in diameter) and dried. The grid was then placed in an electron microscope and electron microscopic studies were performed. All images are obtained in the bright field mode with an accelerating voltage of $100 \mathrm{kV}$.

CNS were introduced into the slip as a part of aqueous solutions (colloidal solutions), in the proportion ranging from 0.5 to $9 \%$ by mechanical stirring. The composition of the resulting samples is given in Table 2 . 
Characteristics of the pith coke

\begin{tabular}{|c|c|c|c|c|c|c|}
\hline \multirow{2}{*}{ Sample } & \multicolumn{3}{|c|}{ Element, \% } & \multicolumn{3}{|c|}{ Technical analysis, \% } \\
\cline { 2 - 7 } & $\mathrm{C}^{\text {daf }}$ & $\mathrm{H}^{\text {daf }}$ & $\mathrm{N}^{\text {daf }}+\mathrm{O}^{\text {daf }}$ & $A^{d}$ & $S_{t}$ & $V^{\text {daf }}$ \\
\hline Pitch coke & 97.84 & 0.43 & 1.18 & 12.1 & 0.95 & 1.7 \\
\hline
\end{tabular}

Table 2

Recipe of nanomodified slip for making samples of ceramics

\begin{tabular}{|c|c|c|c|c|}
\hline Sample & 1 (etalon) & 2 (modified) & 3 (modified) & 4 (modified) \\
\hline \multicolumn{5}{|c|}{$1^{\text {st }}$ series of experiments } \\
\hline Slip & Industrial & Industrial & Industrial & Industrial \\
\hline Water, ml & 50.3 & 40 & 25 & 0 \\
\hline Suspension, $\mathrm{ml}$ & 0 & 10 & 25 & 50.4 \\
\hline Nanoparticles content, $\%$ & 0 & 0.5 & 1.5 & 3 \\
\hline \multicolumn{5}{|c|}{$2^{\text {nd }}$ series of experiments } \\
\hline Slip, mass, kg & Industrial 2 & Industrial 2 & Industrial 2 & Industrial 2 \\
\hline Suspension, $\mathrm{ml}$ & 66.8 & 66.8 & 66.8 & 66.8 \\
\hline Nanoparticles content, $\%$ & 0 & 5 & 7 & 9 \\
\hline
\end{tabular}

Samples which were modified by a molding method were first dried and then forged under the temperature of $1473 \mathrm{~K}$ under factorial laboratory conditions. Etalon and nanomodified samples, dried and forged, were studied for their water absorption and strength (for the dried ones, preforging) and water absorption, strength and porosity (for the forged ones). Furthermore, the contact angle of wetting of the glaze surface was investigated (testing liquid used was plain tap water).Water absorption, flexural strength, air and fire shrinkage were determined according to the standards. To determine the water absorption, the samples were dried in an oven at $383 \pm 5 \mathrm{~K}$ for $1 \mathrm{~h}$, cooled and weighed. The samples were then dried to constant mass. The mass was considered constant if the discrepancy between two consecutive weighings in the 24-hour time interval did not exceed $0.1 \%$ of the resulting value of the previous weighing. The samples were then saturated with water by being boiled for $2 \mathrm{~h}$, after which they were cooled off, dried with a tissue and weighed.
The value of water absorption is calculated according to the formula (1):

$$
E=\frac{m_{2}-m_{1}}{m_{1}} \cdot 100 \%
$$

where $m_{1}$ and $m_{2}$ is the mass of the sample before and after absorbing liquid, respectively.

The shard of product made from made of industrial slip with the addition of the 5\% suspension was examined for the porosity of the structure. The scanning electron microscope (SEM) Jeol JSM 840 was used for this study. Samples were made by cutting fragments from the crock, sample sizes $\varnothing 200 \mathrm{~mm}$. To investigate the dielectric sample of ceramics for the accumulation of negative charge accumulation in the SEM investigation, carbon was sprayed onto the cleavage surface in a vacuum. With the help of EMS, images of the surface were taken with magnifications of $100 \times, 250 \times, 500 \times, 1000 \times, 1200 \times$, and $2500 \times$.

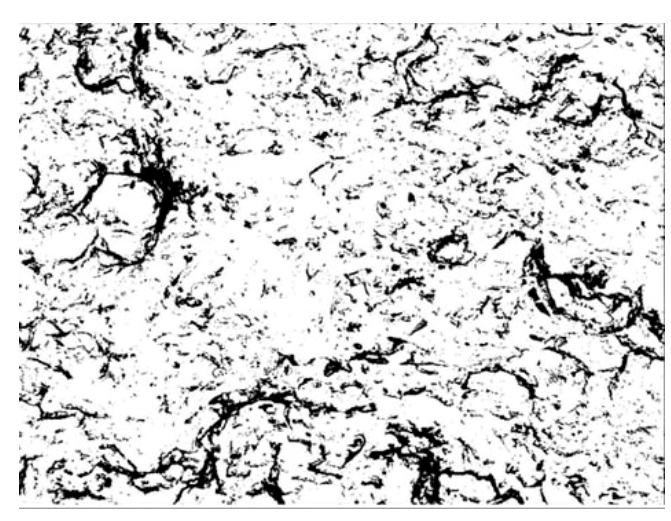

a)

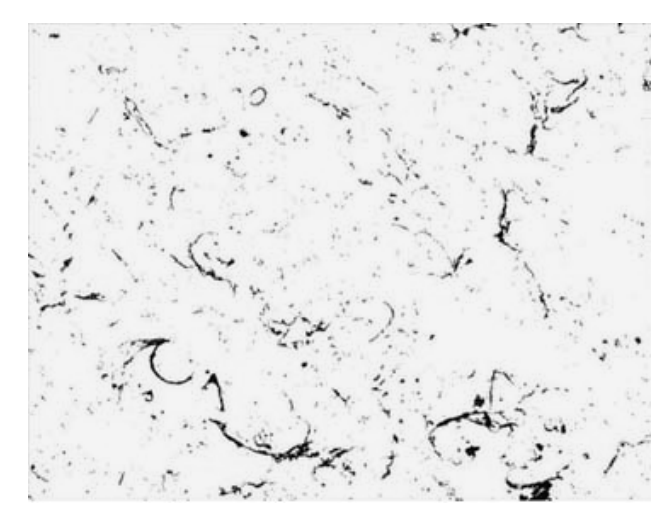

b)

Fig. 1. Image binarization for porosity analysis: reference image (a) and nanomodified ceramics of $5 \%$ nanosuspension (b) 
Using the Image ${ }^{\mathrm{TM}}$ image analyzer [13], the resulting SEM images were analyzed to determine the porosity of the ceramic samples. Binarization of the image for the purpose of porosity analysis is shown in Fig. 1.

The breaking strength was determined in accordance with the standards.

To determine the contact angles of wetting of glazes with nanoadditives, the stationary droplet method has been used. The measurements were carried out using an optical USB-connected electronic microscope with the TopView software.

\section{Results and Discussion}

The morphology of micro- and nanostructures used in a water-based suspension form for modification of the slip are shown in Fig. 2.

With prolonged storage of suspensions the CNS from pitch coke are aggregated into microtubules (diameter from 2 to $8 \mathrm{~mm}$ ) and micro-ribbons (Fig. 3) with the width of up to 30 microns.

The structure of the chips of ceramic samples is shown in Fig. 4.

The results of optical analysis of pores are presented in Table 3. The obtained data shows that samp-

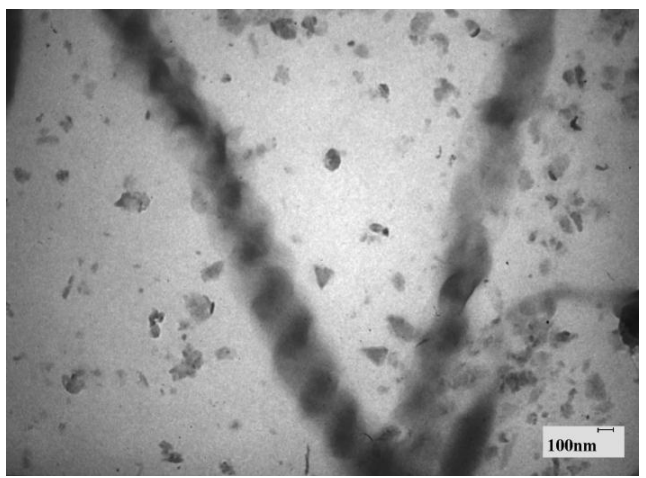

a)

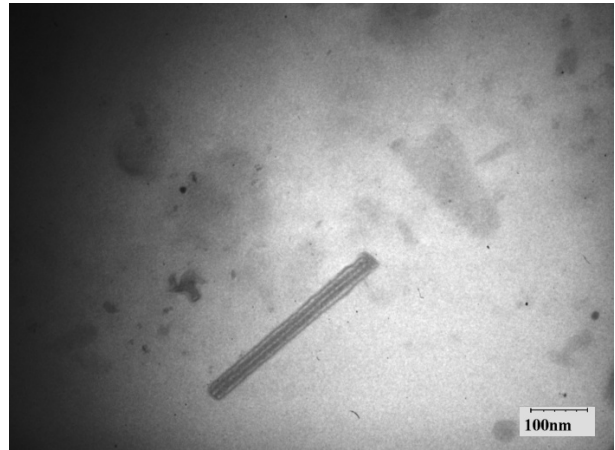

c) les with the addition of 5\% CNS have fewer pores than the reference samples. Thus, the average size of the pores volume from the total analyzed surface of the sample was $6.75 \%$, while for the reference sample this value was $7.5 \%$, although the pore sizes remained practically the same: $3.1-3.3 \mu \mathrm{m}^{2}$.

On average, the porosity of the sample nanomodified with the 5\% suspension was $4 \%$ from the entire mass, which was by $9 \%$ less than the porosity of the reference sample.

Experimental studies have shown that the introduction of nanoadditives affects the properties of the materials obtained. The dampness of the samples just taken out of the mold (first series of experiments) was by $4.1 \%$ smaller than the standard for the third sample (the $1.5 \%$ suspension added), the linear shrinkage was by $23 \%$ lower than that of the etalon sample, and the mechanical strength of the dry sample was greater by $32 \%$. Sample 2 (with the 3\% suspension) showed the lowest fire shrinkage - by $1.9 \%$ less than the reference one and the highest mechanical strength of the calcined sample - by $26 \%$ greater than the etalon. The results of the study of the samples are shown in Fig. 5.

The results of determining the contact angle of the glaze wetting are shown in Fig. 6.

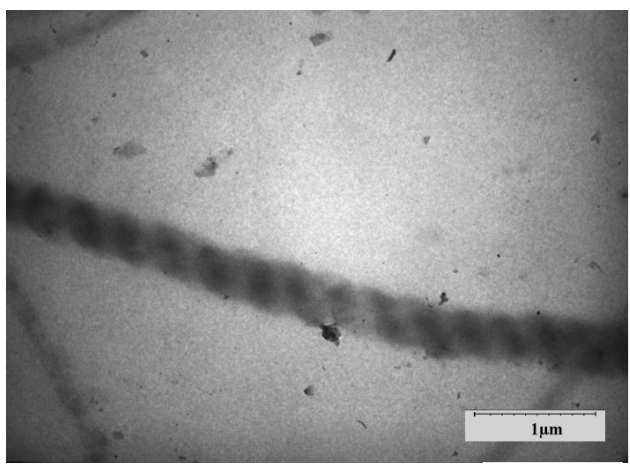

b)

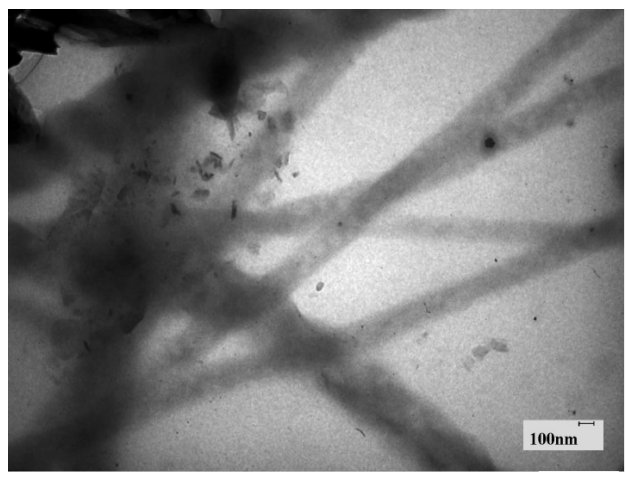

d)

Fig. 2. Morphology of CNS from coke trifle: spiral fibers (a, b) and multi-walled nanotubes (TEM) (c, d) 


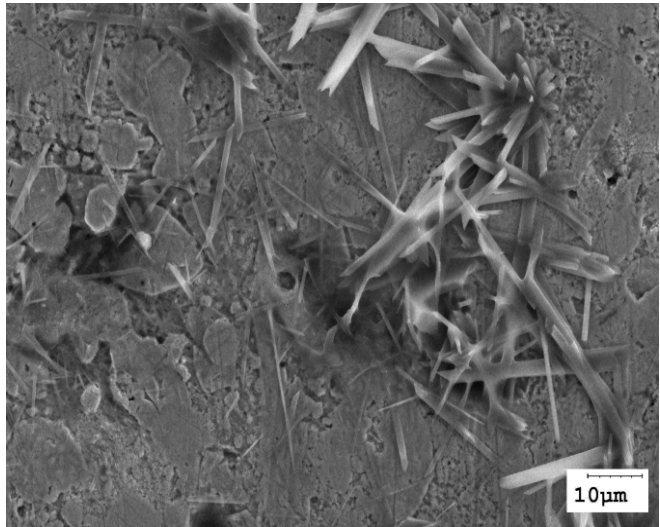

a)

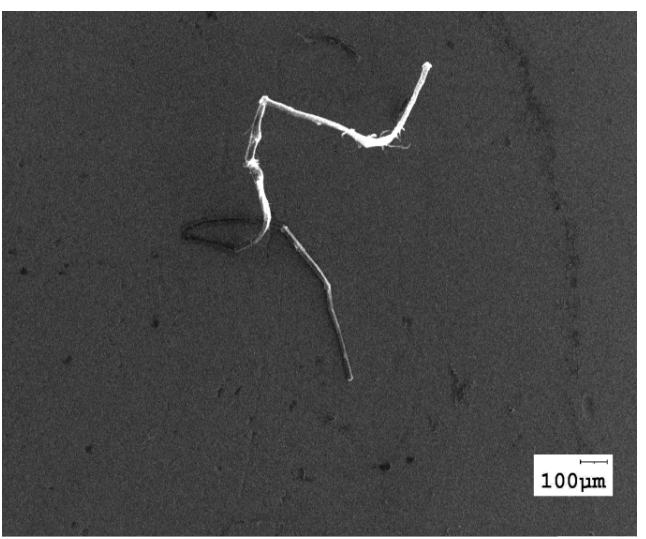

c)

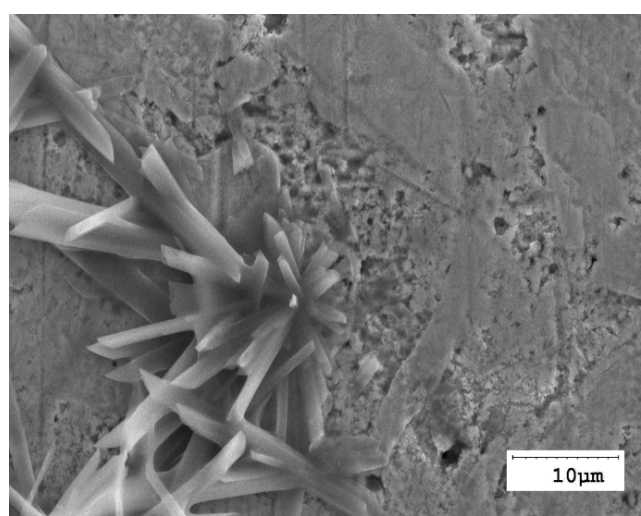

b)

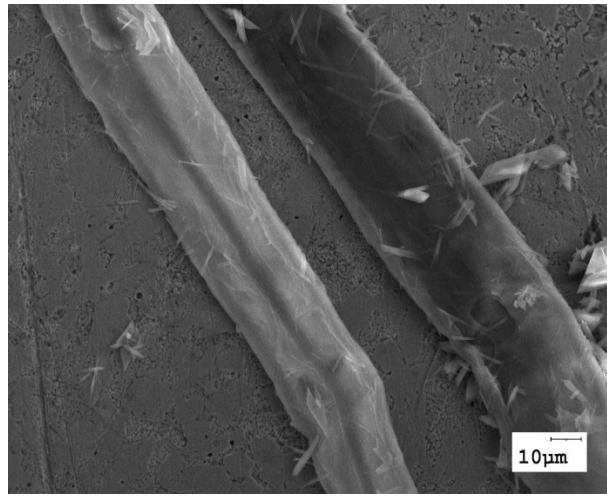

d)

Fig. 3. Agglomerates of CNS suspensions from pitch coke (SEM)

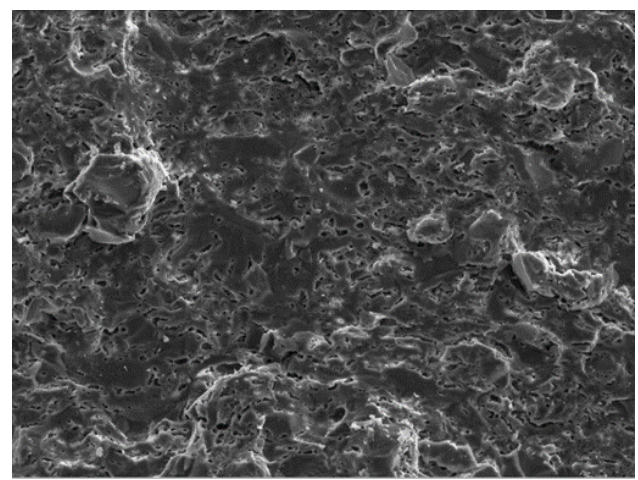

a)

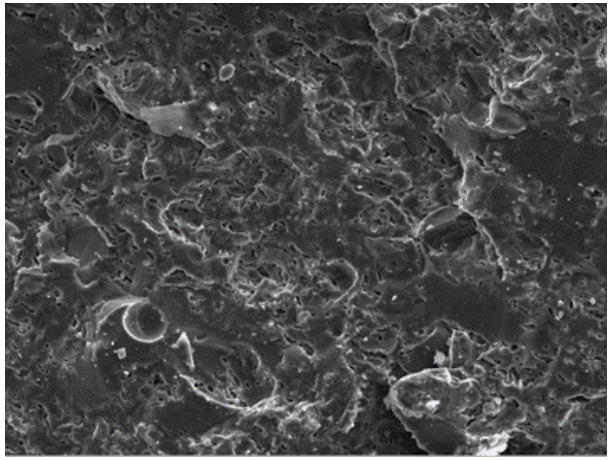

b)

Fig. 4. Images of the surface of the chips of the ceramic: standard (a) and modified by nanoparticles (SEM) (b)

Table 3

Characteristics of the pores of standard and modified samples

\begin{tabular}{|c|c|c|c|}
\hline Sample & Entire surface area, $\mu \mathrm{m}^{2}$ & Average surface area, $\mu \mathrm{m}^{2}$ & $\begin{array}{c}\text { Percentage of pores according } \\
\text { to average surface, } \%\end{array}$ \\
\hline Etalon & 548.6 & 3.3 & 7.5 \\
\hline $5 \%$ CNS & 368.2 & 3.3 & 5.0 \\
\hline $7 \%$ CNS & 501.5 & 3.1 & 6.5 \\
\hline
\end{tabular}




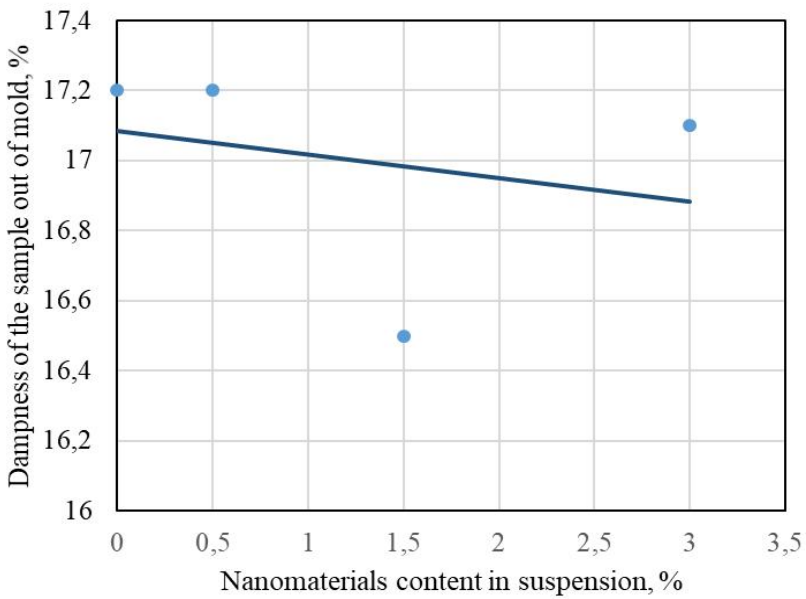

a)

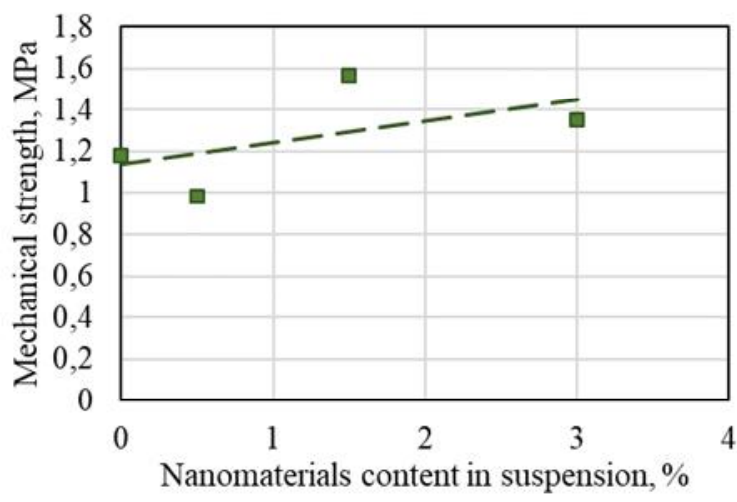

c)

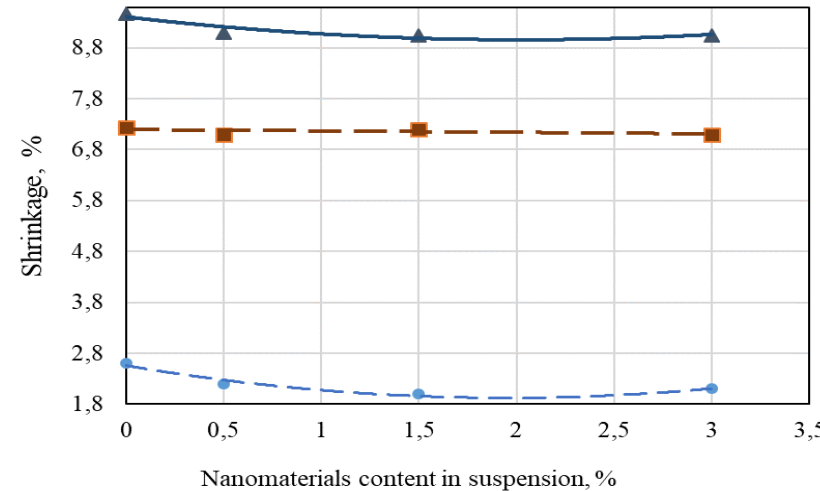

- Linear air shrinkage, \%

ninear heat shrinkage, \%

$\Delta$ Full linear shrinkage, \%

b)

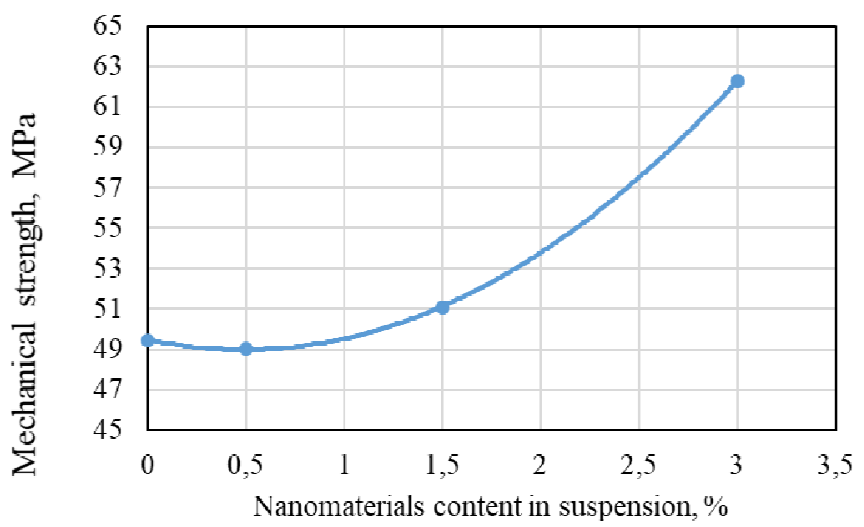

d)

Fig.5. The results of experimental studies of the samples: dampness of samples out of the mold (a); shrinkage of the samples (b); mechanical strength of the samples after drying (c) and mechanical strength of the shard (d)

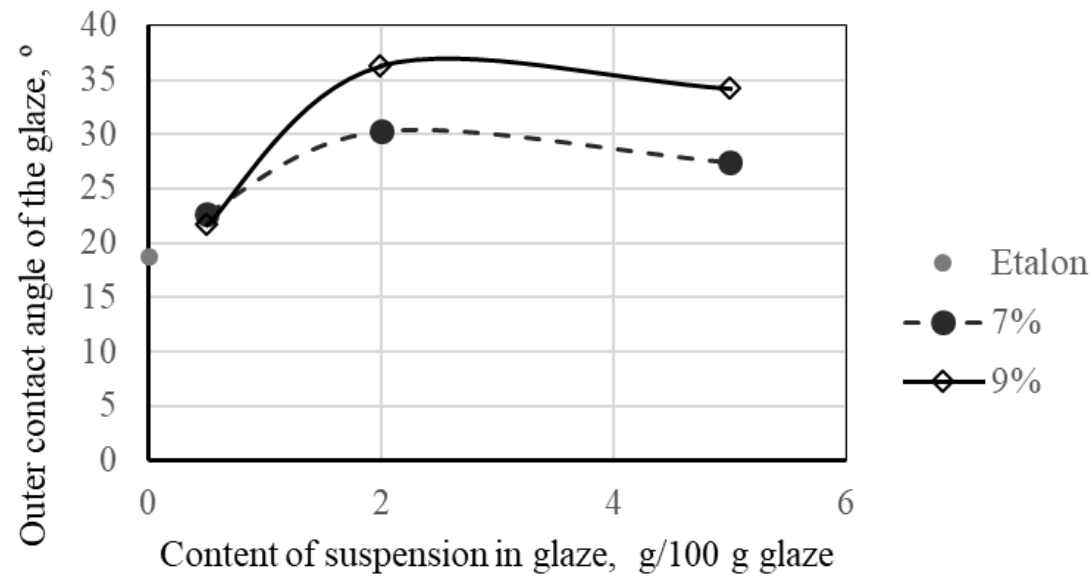

Fig. 6. Outer contact angle of the glaze wetting 
The reference sample has the contact angle of $19^{\circ}$, while all nanomodified samples have a greater contact angle of wetting, the largest of which corresponds to the value of $37^{\circ}$, which was displayed by a sample modified with the $9 \%$ suspension, the content of which in the glaze was $2 \mathrm{~g}$ per $100 \mathrm{~g}$ of glaze $(0.1 \%$ nanoparticles by weight), which is 1.9 times more than that of the reference sample.

\section{Conclusions}

Introduction of nanoparticles (specifically nanofibers obtained from the waste of coke production by pyrolytic method) into the slip that is used for manufacture of sanitary ceramics leads to a change in the properties of ceramic samples, namely, it allows to reduce the moisture content of the sample from the mold, to reduce shrinkage, to increase the strength of dried and calcined samples, and decrease porosity of the burnt shard. The following results were obtained: dampness of the sample nanomodified with the $1.5 \%$ suspension taken straight out of the mold was by $4.1 \%$ lower compared to the standard, air shrinkage was reduced by $23 \%$, and mechanical strength of the dry sample was increased by $32 \%$. A sample which was nanomodified with the $3 \%$ suspension showed the highest mechanical strength - by $26 \%$ higher than the reference sample. The porosity of the sample nanomodified with the $5 \%$ suspension was less than the reference one by $9 \%$, the contact angle of the nanomodified glaze was 1.9 times greater than that of the reference one.

The obtainment of new properties by nanomodified materials might be caused by the changes in thermodynamic states of nanosystems in comparison to classic models, and the manifestation of quantum-sized effects due to a decrease in structural sizes. This results in small particles exhibiting high psyicochemical activity. Thus, nanosystems function as centers of direct crystallization, which results in formation of reinforced structurallyorientated supermolecular shell around nanoparticles and the perforation of pore walls in material decreases. At the same time, the strength of examined porous composites is increased. The increase in wettability of the glaze surface can be explained by decrease of grain size and decrease in the surface roughness.

\section{References}

[1] Hvizdoš P., Puchy' V., Duszova'A., Dusza J.: Carbon Nanofibers Reinforced Ceramic Matrix Composites in Lin T. (Ed.), Nanofibers - Production, Properties and Functional Applications IntechOpen 2011, 241-266. https://doi.org/10.5772/23445 [2] Mukhopadhyay A., Chu B., Green M., Todd R.: Acta Mater., 2010, 58, 2685. https://doi.org/10.1016/j.actamat.2010.01.001 [3] Rodionov R.: Stroit. Mater., Oborudovanie, Technol. XXI veka, 2006, 10, 57.

[4] Yakovlev G., Pervushin G., Lushnikova A. et al.:Proceed. III Int. Conf. "Nanotechnology for Eco-friendly and Durable construction". Egypt, Cairo 2011.

[5] Yakovlev G., Pervushin G., Maeva I. et al.: Procedia Eng., 2013, 57, 407. https://doi.org/10.1016/j.proeng.2013.04.053

[6] Leontev S., Saraykina K.,Golubev V. et al.: Procedia Eng., 2017, 172, 649. https://doi.org/10.1016/j.proeng.2017.02.076

[7] http://icnnc.org/files/day1/2-yakovlev.pdf

[8] Fedorova G., Mestnikov V., Matveeva O. et al.: Procedia Eng., 2013, 57, 264. https://doi.org/10.1016/j.proeng.2013.04.036

[9] Yakovlev G., Kerene Ya., Maeva I. et al.: Intellektual. Sistemy v Proizvodstve, 2012, 2, 180.

[10] http://www.issp.ac.ru/ebooks/conf/innov_mater.pdf

[11] Grishina A., Korolev E.: Key Eng. Mater., 2016, 683, 90. https://doi.org/10.4028/www.scientific.net/KEM.683.90

[12] Shmalko V., Zelensky O., Rudkevich M.: Chem. Chem. Technol., 2013, 7, 359.

[13] Abramoff M., Magalhaes P., Ram S.: Biophotonics Int., 2004, 11, 36 .

Received: August 19, 2018 / Revised: October 01, 2018 / Accepted: November 13, 2018

\section{МОДИФІКАЦІЯ КАРБОНОВИМИ НАНОДОДАТКАМИ КЕРАМІКИ І КЕРАМІЧНОЇ ГЛАЗУРІ ТА ВЛАСТИВОСТІ МОДИФІКОВАНИХ МАТЕРІАЛІВ}

Анотація. Розглянуто спосіб модифікації керамічних матеріалів внаслідок введення карбонових нанододатків у вигляді водної суспензї до складу шлікера і керамічної глазурі для виготовлення санітарно-технічної кераміки. Досліджено фізико-механічні властивості зразків. Отримано результати експериментальних досліджень властивостей композиційних матеріалів, наномодифікованих карбоновими наноструктурами.

Ключові слова: наноструктура, кераміка, глазур, санітарно-технічні вироби, пористість, крайовий кут змочування. 